
Edyta SWEKLEJ

\title{
DOGS' AGGRESSIVE BEHAVIORS \\ PART I. NEUROBIOLOGICAL MECHANISMS AND ANIMALS' PREDISPOSITIONS
}

\section{ZACHOWANIA AGRESYWNE PSÓW CZESŚĆ I. MECHANIZMY NEUROBIOLOGICZNE ORAZ PREDYSPOZYCJE ZWIERZĄT}

Department of Cattle, Sheep and Milk Evaluation, Siedlce University of Natural Sciences and Humanities, Poland

\begin{abstract}
Streszczenie. Nadmierna nerwowość czworonogów w ostatnich latach jest zasadniczym problemem wpływającym na negatywny odbiór zwierzęcia przez otoczenie, jak również bezpośrednio oddziałująca na jego organizm. Umiejętność rozpoznawania emocji psa pozwala na prawidłową reakcję właściciela zapobiegającą eskalacji złego zachowania, a w konsekwencji atakowi. $Z$ tego względu podjęto próbę charakterystyki zachowań agresywnych psów, określenia ich przyczyn związanych z czynnikami neurobiologicznymi oraz predyspozycjami genetycznymi, a także z możliwościami zapobiegania oraz skutkami wywieranymi na otoczenie.
\end{abstract}

Key words: aggression, dogs, neuroscience.

Słowa kluczowe: agresja, pies, neurobiologia.

\section{INTRODUCTION}

In today's world, pet animals occupy a very important part of our lives. They provide a refuge from the fatigue of everyday life, may relieve stress, play a therapeutic role, and are also excellent companions of children and adults. According to the Central Statistical Office (2014), there are approx. 8 million dogs in Poland. A survey carried out by TNS Polska in October 2014 on a group of 1000 people aged 15 and over showed that $83 \%$ of Poles who have pets in the household - have dogs. The majority of respondents $(87 \%)$ declare that dogs are man's best friends. Thanks to them, people establish positive relationships with each other, form hobby and mutual-help groups, but the lack of good knowledge on the behavior of dogs and how to react properly in a dangerous situation can lead to many unnecessary conflicts (O'Sullivan et al. 2008; Horn et al. 2013). In recent years, the problems of dog-on-dog aggression and attacks on caregivers or family members have been absorbing much attention. Studies show that $65.3 \%$ of bite perpetrators are mixed-breed dogs, and purebred dogs account for $31 \%$ cases, of which $14 \%$ are by German shepherd dogs, $4.1 \%$ by dachshunds, whereas other breeds represent isolated cases only. As many as $67 \%$ of dog bite cases happen in the dog's territory, i.e. the house or backyard (Landsberg et al. 2003; Fiszdon and Boruta 2012; Fiszdon and Boruta 2013).

Corresponding author - Adres do korespondencji: Elżbieta Horoszewicz, Department of Cattle, Sheep and Milk Evaluation, Siedlce University of Natural Sciences and Humanities, Bolesława Prusa 14, 08-110 Siedlce, Poland, e-mail: ehoroszewicz@wp.pl 
One of definitions of aggression says about a behavior aimed to defend the sphere of psychological and physical comfort, regardless of the consequences to the body (pain, fear, injuries). Early detection of the dog's emotions, escalation of which could lead to an attack, gives the carer the opportunity to respond adequately. To determine the predictability and selfcontrol of the animal, one needs to thoroughly analyze the process of an aggression act. This analysis involves the level of violence, the kind of attack and the type of aggression (Petrynka et al. 2014).

\section{NEUROBIOLOGICAL GROUNDS OF AGGRESSION}

Researchers involved in the still developing field of aggression studies, trying to explain the activity of the brain under high-arousal conditions, base their investigations on neuroscience, combining elements of biochemistry, molecular biology, physiology, anatomy and medicine. In many psychiatric disorders, such as phobias, hypersensitivity or obsessive-compulsive disorder, it is excessive nervousness which is a serious problem that negatively affects the environment and the health of the animal (Riva et al. 2008; Longstaff 2009; Kania et al. 2012).

Aggression is controlled by the sophisticated limbic system, which includes the hippocampus, hypothalamus, amygdala, cingulate gyrus, midbrain and the thalamus. The cerebral cortex interacts with the system. The core of the system activity is a direct response to environmental input, both external and internal, which may be crucial for the survival of the animal, and the analysis of the situation in terms of possible or real threats. The limbic system is involved in firing positive or negative emotions, sexual drive responses and the need to acquire food. It also affects cognitive abilities, selection of action tactics adequate to the situation (learning and memorization) and triggers an effective behavioral response (decision-making processes: attack or escape).

The system evokes and inhibits aggressive responses, and contains their neuromodulators and transmitters (Świerkocka-Miastkowska et al. 2005; Riva et al. 2008). The role of the thalamus is to relay sensory impulses from receptors located in various parts of the body. Sensory fields of the thalamus control the emotional response. Excitation of the field triggers an emotion, such as joy or anger. Because the amygdala and thalamus interact, the dog is able to focus on the task it has to perform. This is due to the lack of perception of environmental stimuli by the consciousness of the dog. Below in the limbic system is the hypothalamus, responsible for aggression and escape, controlling the feelings of hunger, satiety, thirst, need for sleep and rest, and also secreting testosterone, whose high levels in the body may intensify aggression. Interacting with other systems, it has a significant impact on the conditioned and unconditioned emotional responses (Borodulin-Nadzieja et al. 2004; Beszczyńska 2007).

The amygdala is a structure that is responsible for initiating self-preservation behaviors (e.g. defense and aggression), controls the release of certain hormones and is responsible for association and memorization of emotions linked with the given situation. It is a kind of information storage system of emotions like fear and anger. Damage to the amygdala leads to elevated alertness, which - in consequence - increases aggression (Bartkowska 2004; Świerkocka-Miastkowska et al. 2005). Analysis, comprehension and processing of the torrent of information that reaches the brain belongs Lato Lightto the cingulate gyrus. Activation of the 
anterior cingulate gyrus occurs if the tasks to accomplish requires a high level of emotional load. The posterior cingulate is activated when the response causes annoyance or spite. Aggressive behaviors can thus be controlled and their intensification depends on their current analysis, i.e. whether they are positive for the individual or not. Damages to this part of the system impairs conditioned defense responses of avoidance type (Fąfrowicz and Marek 2008). The medial temporal lobe of the brain includes a structure called the hippocampus.

Its main role is to create the learning process and memories, to remember emotions and to produce new nerve cells. Working with other parts of the brain, the hippocampus uses experience and emotional memory in order to produce a response leading to achieving a specific goal. For example, the dog learns that showing teeth and uttering certain sounds will make the human or the animal move back from the dog itself or its objects (like the bowl or the seat of the carer; this is called negative reinforcement). The structure, which is the control mechanism of the attack, belongs to the incentive system and the system that shapes the motor component of aggression. Impulses activating aggression come mainly from the olfaction and vision senses, and the initiating stimuli are special acts of movement, sounds and touching (Śliwowska et al. 2012).

The transmission of information is the domain of neurons and neurotransmitters. Those latter that stimulate and inhibit aggression include dopamine, serotonin, glutamate, and GABA (gamma-aminobutyric acid). Dopaminergic neurons, which together form dopaminergic systems, are the main source of dopamine. These are responsible for the process of learning and memorization, motor coordination, attention focusing, control of emotional and motivational functions. Increased levels of dopamine in the body makes the animal restless, agitated and more sensitive to external signals. Lower dopamine production reduces the level of endorphins and worsens the animal's mood (Fish et al. 2002; Drożak and Bryła 2005; Riva et al. 2008; Vetulani 2013). The serotonin system is the most widely distributed system in a vertebrate brain. Its functions include regulation of the balance, energy resources through sleep and relaxation, and the temper. Low serotonin evokes irritability and increases the frequency of nervous impulses, which in consequence leads to aggressive behavior. A low level of this neurotransmitter has an effect on the violence of attack. Affected dogs do not show signs of warning, their attacks are more furious and bites are worse, compared to dogs with a normal level of serotonin (Kania et al. 2009; Vetulani 2013). It is important that the level of neurotransmitters be in equilibrium, since any disorder in their concentrations may lead to excessive or inhibited mental reactions, such as (too high or too low) pain threshold, sensitivity to stress, overreacting and aggression (Fish et al. 2002; Pietruczuk and Witkowski 2008; Jakubczyk and Wojnar 2009). The mechanism of aggression is controlled by many interacting and specialized systems, which are in turn controlled by the brain - susceptible not only to genetic factors, but also to environmental influences.

\section{GENETIC PREDISPOSITION AND ENVIRONMENT FACTORS OF AGGRESSIVE BEHAVIOR}

The development of emotions and the ability to handle input received from external world starts in the fetal life of the young organism. Malpractice or mistreatment of the beach in pregnancy and the puppies during their growth and development may result in bad behaviors that will be difficult or even impossible to eradicate (Horn et al. 2013). 
There are different phases and periods of intensified sensitivity in every growing and developing mammal. In dogs, these phases vary in length depending on the breed and the size of the dog. As a rule, small dogs reach maturity sooner and go through the different stages quicker than dogs of large breeds. We must not forget that the dog learns throughout life and may at any time find out that aggression allows it to achieve the desired effect (Serpell and Jagoe 1995; Pal 2010). The first step is the prenatal stage, in which mainly hormones affect fetal development. Studies by various authors show that beaches which experience a high level of stress during pregnancy give birth to puppies that are more emotional and reactive, while females that are dominant in character, or have been treated with testosterone, produce puppies that reveal more masculine pattern of behavior, are more territorial and more dominant (Goleman 2008; Pal 2010; Foyer et al. 2013).

From the moment of birth until 14 days of age, the young canine is in the neonatal period of life. To a large extent, the input from the outside at that time is limited to sensations of heat (the period when structures responsible for the regulation of body temperature develop), hunger and mother's presence. The basic stimulator of adaptive behavior is the mother. This is also the moment when the first phase of fear appears. If at that time the puppy experiences strong, long-lasting, negative stimuli, it may end up with irreversible damages to the dog's mental health. Observations carried out at that time in neonates suggest that frequent stroking, tender touching or lifting by a human provides positive stimulation of the nervous system and accelerates its development. Additional smell signals stimulate the development of the olfaction. The animals grow emotionally more stable, more resistant to stress and more eager to learn about the surrounding world (Pal 2008). Maturation of the nervous system and senses falls on the so-called transitional period (from 14 to 21 days of age).

The response to external input grows stronger at that time. New motor skills develop, such as stable movement and tail wagging. At this stage, the dog does not tolerate changes or the unknown. Contacts with adult people or children started during this period reduce the incidence of aggressive reaction in the future adult life. Three weeks after birth, the so-called primary socialization period starts and lasts until about eight weeks of age. This is the most delicate and also the most important time in the social development of the dog. The process of myelination of the spinal cord has been fully completed, the nervous system is already mature and receives all stimuli from the external environment. The animal is more willing to explore the world in which it grows, and plays with siblings and the mother. For the first time, frolic turns into playing postures that are signals of dominance, submission or helplessness. This is also the fear imprint time, hence it is very important to provide the puppies with positive stimuli, so that they could easily get rid of anxiety.

Research conducted by Seksel (1999), Goleman (2008) and Storengen (2015) showed a correlation between anxiety in this development stage and the ability to interact with people and animals in adulthood. Lack of mature and adequate defense mechanisms and reactions have been the most common source of fear-driven aggression. Adolescence, which starts as soon as the primary socialization period ends, has its final in the puberty. The animal's senses and motor coordination improve, and so does the ability to concentrate. At 4-8 months of age, the dog begins to explore the surrounding area on its own, often refuses to come on cue. At age 6 to 14 months, the dog experiences a hormone surge and its behavior may be 
unintelligible for the owner, due to anxiety or aggression triggered by incidents so far treated as neutral. Any mistakes made in the preceding months of the dog's life now result in problems of this kind or another. Males show new behaviors stimulated by androgens, including wandering, jumping up and marking. Also territory-, defense- and dominance-based aggression incidents are often the case (Fiszdon 2004; Hsu et al. Sun 2010). Senility is the final stage of life. The body weakens and so do mental functions, although one should not neglect mental stimulation of the aging dog. Without it, the dog may become more bad-tempered, sluggish, "depressive", which in consequence may lead to annoyance-type aggression. This phase is often accompanied by confusion and changes (limitation) in the interactions with humans, longer sleep and apathy (Fiszdon 2004; Christensen et al. 2007).

The genetic grounds of aggressive behavior, or aggressive disposition, are closely related to the breed of the dog. Some breeds exhibit a stronger drive to aggression or undertake specific actions that can turn into aggressive behavior. It has not been elucidated, however, which groups of genes are responsible for it. This issue is a major challenge for canine science; the aim of this research is to develop breeding and selection methods which would exclude individuals affected by aggression. The following examples are worth considering:

- livestock guardian dogs - they have a strong territorial instinct. They may show aggression to strangers who enter their territory. If improperly trained or unsocialized, these dogs gradually become fearful and feeling insecure in social interaction;

- property guard dogs - the genetic work in this group produced individuals in which body posture, vocalization and strong territorial instinct, along with obedience to the owners, are the most important traits. The character of a watchdog is marked by independence and quick reaction;

- herding dogs - because of their intelligence and inexhaustible energy, these dogs may devastate their surrounding; however, selection carried out by professional breeders has greatly reduced the incidence of aggressive individuals in this group;

- terriers - through appropriate trait selection, these dogs have been prepared to hunt and kill other animals. A strong hunting instinct may be an obstacle to form packs with smaller dogs;

- hounds - have a strong need for tracking game animals. Smaller animals, such as cats or rabbits are in danger if found in their territory. A large amount of energy that is not consumed finally finds an outlet in destructive acts and problematic behavior patterns;

- primitive breeds - dogs with a strong foraging instinct. If the dog is left without care or basic training, it will be attacking any animal and even the guardian. They are known for spectacular escapes, often jumping over a high fence (Svatberg 2006).

\section{SUMMARY}

Understanding the mechanisms of the nervous system that are responsible for aggression, as well as learning the genetic and environmental factors affecting it, will allow designing appropriate training systems and will provide better communication between the dog and the environment in which it resides. In extreme cases, such as phobias or obsessive-compulsive disorder, the knowledge allows application of appropriate pharmacological treatment. Also negligence of the knowledge on how environmental factors contribute to hyperexcitability may form inappropriate relationships between the young animal and the environment. 


\section{REFERENCES}

Bartkowska K. 2004. Generacja komórek w mózgu dorosłych zwierząt [Neurogenesis in the brain of adlut animals]. Kosmos, 53, 167-181. [in Polish]

Beszczyńska B. 2007. Molekularne podstawy zaburzeń psychicznych wywołanych stresem [Molecular basis of stress-evoked psychiatric disturbances]. Post. Hig. Med. Dośw. 61, 690-701. [in Polish]

Borodulin-Nadzieja L., Woźniak W., Tumińska A., Całkosiński R. 2004. Rola układu oreksynowego. I. Regulacja przyjmowania pokarmów [Role of the orexins system. I. Feeding regulation]. Adv. Clin. Exp. Med. 13(4), 689-695. [in Polish]

Christensen E., Scarlett J., Campagna M., Houpt K.A. 2007. Aggressive behavior in adopted dogs that passed a temperament test. App. Anim. Beh. Sci. 106, 85-95.

Drożak J., Bryła J. 2005. Dopamina - nie tylko neuroprzekaźnik [Dopamine: not just a neurotransmitter]. Post. Hig. Med. Dośw. 59, 405-420. [in Polish]

Fąfrowicz M., Marek T. 2008. Przedni zakręt kory obręczy - perspektywa neurokogniwistyczna [Anterior cingulte cortex - a neurocognitive perspective]. Prz. Psychol. 51(2), 149-160. [in Polish]

Fish E.W., De Bold J.F., Miczek K.A. 2002. Aggresivve behavior as a reinforcer in mice: A ctivation by allopregnanolone. Psychopharmacology 163, 459-466.

Fiszdon K. 2004. Kształtowanie zachowania się psów w okresie szczenięcym [Behaviour patterns development during puppyhood]. Życie Wet. 79(5) 249-254. [in Polish]

Fiszdon K., Boruta A. 2012. Analiza przypadków pokąsania przez psy. Część I. Jakie psy kąsają? [Analysis of dog biting incidents. Part I. Which dogs bite?]. Życie Wet. 87(12), 1022-1026. [in Polish]

Fiszdon K., Boruta A. 2013. Analiza przypadków pokąsania przez psy. Część II. Kim są ofiary pokąsań? [Analysis of dog biting incidents. Part II. Who are the victims?]. Życie Wet. 88(3), 213-217. [in Polish]

Foyer P., Wilsson E., Wright D., Jensen P. 2013. Early experiences modulate stress coping in a population of German shepherd dogs. App. Anim. Beh. Sci. 146, 79-87.

Goleman M. 2008. Wpływ warunków utrzymania w hodowlach owczarków niemieckich na rozwój psychiczny szczeniąt [Impact of maintenance in German Shepherd Dogs breeding on psychologybdevelopment of puppies]. Rocz. Nauk. PTZ 4(4), 185-193. [in Polish]

Horn L., Range F., Huber L. 2013. Dogs' attention towards humans depends. On their relationship, not only on social familiarity. Anim. Cogn. 16, 435-443.

Hsu Y., Sun L. 2010. Factors associated with aggressive responses in pet dogs. App. Anim. Beh. Sci. 123, 108-123.

Jakubczyk A., Wojnar M. 2009. Impulsywność - definicje, teoria, modele [Impulsiveness - definitions, theories, models]. Post. Psych. Neurobiol. 18(4), 349-356. [in Polish]

Kania B., Zawadzka E., Dębski B. 2012. Neurohormonalne podstawy agresji u ryb [Neurohormonal basis of aggression in fish]. Med. Weter. 68(4), 195-198. [in Polish]

Landsberg G., Hunthausen W., Ackerman L. 2003. Handbook of behavior problems of the dog and cat. Edinburgh, Saunders.

Longstaff A. 2009. Neurobiologia. Krótkie wykłady. Warszawa, Wydaw. PWN. [in Polish]

O'Sullivan E.N., Jones B.R., O'Sullivan K., Hanlon A. 2008. The management and behavioural history of 100 dogs reported for biting a person. App. Anim. Beh. Sci. 114, 149-158.

Pal S.K. 2010. Play behaviour during early ontogeny in free-ranging dogs (Canis familiaris). App. Anim. Beh. Sci. 126, 140-153.

Petrynka M., Olczak K., Klecek C. 2014. Zachowania agresywne zwierząt [Agressive behaviour in animals]. Prz. Hod. 4, 30-32. [in Polish]

Pietruczuk K., Witkowski J. 2008. Lithium sals-mechanismis of action. Psychiatria 5(2), 51-57.

Riva J., Bondiolotti G., Michalazzi M., Verga M., Carenzi C. 2008. Anxiety related behavioural disorders and neurotransmitters in dog. App. Anim. Beh. Sci. 114, 161-181. 
Seksel K., Mazurski E.J., Taylor A. 1999. Puppy socialization programs; short and long term behavioral effects. App. Anim. Beh. Sci. 62, 325-349.

Serpell J., Jagoe J.A. 1995. Early experience and the development of behaviour, the domestic dog. Cambridge University Press, 79-102

Storengen L.M., Lingaas F. 2015. Noise sensitivity in 17 dog breeds: Prevalence, breed risk and correlation with fear in other situations. App. Anim. Beh. Sci. 171, 152-160.

Svatberg K. 2006. Breed-typical behaviour in dogs: Historical remnants or recent constructs? App. Anim. Beh. Sci. 96(3-4), 293-313.

Śliwowska J., Górecki M., Tryjanowski P. 2012. Wprowadzenie do neurologii - czyli czy znajomość układu nerwowego zwierząt pozwala zrozumieć ich relacje ze środowiskiem [A short introduction to neuroecology]. Kosmos 61, 195-211. [in Polish]

Świerkocka-Miastkowska M., Klimarczyk M., Mazur R. 2005. Zrozumieć układ limbiczny [To comprehend the limbic system]. Psych. Prak. Ogól. 5(1), 47-50. [in Polish]

Vetulani J. 2013. Neurochemia impulsywności i agresji [Neurochemistry of impulsiveness and aggression]. Psych. Pol. 47(1), 103-115. [in Polish]

Abstract. Excessive nervousness of a dog may not only disrupt the positive social perception of the animal, but also directly affects its health. Expertise in recognition of the dog's emotions allows the owner to properly respond to its bad behavior, preventing the outburst of anger and a possible attack. For this reason, we attempt to characterize aggressive behaviors in dogs and the underlying neurobiological factors and genetic predisposition to aggression, and we also address some preventive measures and possible consequences of the aggressive behavior to the environment. 
